\title{
The Service Performance in the Field of Islamic Community Guidance at the Ministry of Religion of Hulu Sungai Tengah Regency
}

\author{
Ristya Nurjannah; Budi Suryadi; Hairudinor \\ Lambung Mangkurat University, Banjarmasin, Indonesia \\ http://dx.doi.org/10.18415/ijmmu.v8i9.3028
}

\begin{abstract}
This research sought to analyze the Service Performance of BP4 (The Board of Marriage Development and Preservation) in the field of Muslim Guidance at the Ministry of Religion of Hulu Sungai Tengah Regency and to identify the existing constraint factors. This research employed a case study method with a research approach. Data collection techniques used in this research were interview, observation, and documentation. The research results revealed that: 1) the service performance of BP4 in the field of Islamic Guidance at the Ministry of Religion of Hulu Sungai Tengah Regency on the performance indicators of quality, quantity, timeliness, cost effectiveness, need for supervision, and interpersonal impact is quite good and 2) the existing constraint factors are the timeliness during service process where service users are not present during mediation process and the occasional difficulties faced when extracting service user data.
\end{abstract}

Keywords: Performance; Service; Field of Islamic Community Guidance

\section{Introduction}

The "good governance" principle implementation in government management has become a major demand, which is marked by the increasing community involvement in monitoring and evaluating the benefits and values obtained from services provided by government agencies. Bureaucracy is shifting from a centralized to decentralized paradigm, from authoritarian to egalitarian and democratic, from state sovereignty to people sovereignty, from large organization to lean but rich in functions, as well as from rowing (independent work) to steering (directing). Performance can be defined as all the results produced on a specific job

function or activity during a specific period. Overall performance of a job is equal to the sum or average of performance on important job functions. According to Miner (1990), performance is how a person is expected to function and behave in accordance with the assigned tasks. In other words, it refers to any expectations about how a person should behave in carrying out tasks, indicating a role in the organization.

As stated in the Law Number 25 of 2009 concerning Public Services, which regulates the principles of good governance or the effectiveness of government functions, public services carried out by governments or effective corporations can strengthen democracy and human rights, promote economic 
prosperity, social cohesion, reduce poverty, increase environmental protection, manage the use of natural resources better, as well as deepen trust in government and public administration.

The Ministry of Religion of Hulu Sungai Tengah Regency provides services that deal directly with the community in the field of Islamic Community Guidance through the services provided by BP4. This agency handles household problems with data in January-March 2021 can be detailed as: in January with 2 people in and

0 person out, in February with 4 people in and 0 people out, in March with 8 people in and 4 people out (see appendix). The few service users who came to the office of the Ministry of Religion, especially in the field of Islamic Community Guidance provided by BP4 was due to this service being available only for those with civil servants (PNS) status.

The results of previous research revealed that the estimated time that has been set by the Ministry of Religion is one month for BP4 services. However, the time needed for the BP4 services in JanuaryMarch data exceeded the specified time limit. Seeing the disparity between the number of incoming and outgoing numbers, as well as the poor timeliness of service, it is necessary to do further deepening of the service performance in the field of Islamic Community Guidance at the Ministry of Religion of Hulu Sungai Tengah Regency in order to analyze out the performance and identify the constraining factors.

\section{Research Method}

The research employed qualitative approach. Qualitative research only results in finding problems faced by the community by being oriented to field data. This type of research is considered more suitable for research whose objective is to describe service performance in the field of Islamic Community Guidance at the Ministry of Religion of Hulu Sungai Tengah Regency. The research method used in this research was a case study. The instrument was the researcher herself. The informants consisted of thirteen people, namely; the Head of the TU Sub-Division, the Head of the Islamic Community Guidance Section, an Islamic Community Guidance staff, and ten service users. The data collection techniques used to obtain data on service performance in the field of Islamic Community Guidance at the Ministry of Religion of Hulu Sungai Tengah Regency were as the following:

\section{Interview}

Interview is used as a data collection technique when the researcher wants to conduct a preliminary research to find problems that must be investigated. It can also be used if the researcher wants to gain information from respondents more deeply. Interview can be conducted in a structured or unstructured manner, and can be conducted face-to-face or by phone.

\section{Observation}

In observation, the researcher is involved with the daily activities of the person being observed or used as a source of research data.

\section{Documentation}

Document is a record of events that have occurred. Document can be in the form of writing, images, or manual works from someone.

The data analysis technique used in this research adopted the Miles and Huberman model of interactive model. The data obtained by the researcher were based on the results of observations, interviews and documentation in the field, so in the next stage the researcher would analyze the data by:

1. Data reduction, namely selecting data and information found in the field and then analyzing it.

2. Presenting the reduced data. 
3. Drawing conclusions from the data that has been presented from the results of interview, observation, and documentation.

4. Interpreting the data and testing the validity of the data that has been concluded by using triangulation techniques.

\section{Finding and Discussion}

To facilitate understanding, the researcher described the results and discussion of the research on service performance in the field of Islamic Community Guidance at the Ministry of Religion of Hulu Sungai Tengah Regency using service performance indicators proposed by Bernadin and Russell (in Ruky, 2002: 15) which include: 1) quality, 2) quantity, 3) timeliness, 4) cost effectiveness, 5) need for supervision, and 6) interpersonal impact.

\section{The Service Performance in the field of Islamic Community Guidance at the Ministry of Religion of Hulu Sungai Tengah Regency}

Based on the research results that has been carried out by the researcher on several informants, a description of Service Performance in the Field of Islamic Community Guidance at the Ministry of Religion of Hulu Sungai Tengah Regency was obtained. More details are presented in the following discussion:

\section{Quality}

Quality is the degree to which the process or results of implementing activities are close to perfection or close to the expected goals. Quality is also one of the important factors in an agency where the good and bad performance of an agency can be measured from the quality of existing resources. According to Goetsch and Davis (2005), quality is a dynamic condition related to products, services, people, processes, and the environment that meet or exceed what is expected.

Based on the research results and the description above, it can be seen that the quality of service performance in the existing BP4 services in the Field of Islamic Community Guidance is already good. Service officers provide excellent service and carry out their duties and responsibilities in accordance with applicable regulations. Service officers are also equipped with appropriate competencies to ensure that the services can run optimally. This is in accordance with what was expressed by Prawirosentono (in Pasolong, 2007: 176) who argues that performance is the result of work that can be achieved by employees or groups of employees in an organization, in accordance with their respective authorities and responsibilities in an effort to achieve organizational goals in legal manner, which does not violate any laws regarding morals and ethics.

\section{Quantity}

Quantity is the amount of results produced, such as the money and the cycle of activities carried out by employees in a certain period. To provide good service to the community, an organized system is needed. A good service system can reduce extortion and corruption. Clear service requirements, time limits, procedures, and transparent service rates can encourage the level of public confidence in government services.

Based on the research results and the description above, the quantity of services provided by BP4 services in the field of Islamic Community Guidance is not good. It is due to the incompatibility of data on BP4 service users between ins and outs. This is in accordance with what is defined by Simamora that the definition of employee work is the level of employee work results in achieving the given worker requirements. In other words, performance is the work of employees in terms of quality and quantity based on the specified work standards. 


\section{Timeliness}

Timeliness is the extent to which an activity is completed at the desired time, taking into account the coordination of other outputs and the time available for other activities. This is stated in the Decree of the Minister of State Apparatus Empowerment Number: 63/KEP/M.PAN/7/2003 on the point of time certainty which reads public implementation can be completed within a predetermined period of time.

Based on the research results, it can be seen that the estimated timeliness of BP4 services in the field of Islamic Community Guidance is not good. It is due to the mismatch of service time with the estimated time set by the Ministry of Religion of Hulu Sungai Tengah Regency. The service time depends on the existing conditions and situations such as the service process both at the time of extracting data and calling the client. If the process is completed quickly, then the service process will also be completed quickly.

\section{Cost Effectiveness}

Cost Effectiveness is the optimized use of resources to achieve the best results. The ability of employees to use assistive devices is really needed. Every employee has different tasks, so the ability to use assistive devices is needed in order not to bother other employees in completing their tasks. Based on the research results, that the ability of employees to use assistive devices in providing services in the field of Islamic Community Guidance is good, as can be seen from the results of interviews with several service users who explained that service officers can use assistive devices properly. Although sometimes there are problems with those who could not operate computers, the service officers can handle them by asking for help from their co-workers. This is in accordance with the theory of Moenir (2002), namely at the point of the ability and skill factor which reads with adequate abilities and skills, the implementation tasks or jobs can be done well, quickly, and meeting the wishes of all parties in order to achieve satisfactory service.

\section{Need for Supervision}

Need for Supervision is the degree to which an employee can perform a job function without requiring the supervision of a supervisor. Each employee has different tasks and responsibilities. Based on the research results, the ability of service officers in providing services is quite good, service officers are skilled and very competent in providing services. The ability of service personnel without the need for other people is also good, only needed if there are obstacles. This is in accordance with Simamora's theory regarding psychological factors of perception, attitude, personality, and learning.

\section{Interpersonal Impact}

Interpersonal impact is the degree to which employees maintain a good name and cooperation with co-workers, superiors, and subordinates. Based on the research results, the constraint factors existing in the field of Islamic Community Guidance, especially in BP4 service are found in the quantity and timeliness aspects. Specifically, the amount of ins and outs of monthly data on BP4 service users do not match. Time discrepancy is also one of the constraint factors, the estimated service time set by the Ministry of Religion of Hulu Sungai Tengah Regency in the field of Islamic Community Guidance, especially in BP4 services is one month, but on practice it exceeds one month. This is because during the data mining process and at the time of the call for mediation the person concerned has problems attending.

The Constraining Factors of Service Provision in the field of Islamic Community Guidance at the Ministry of Religion of Hulu Sungai Tengah Regency Various constraint factors are found in the service performance of BP4 in the field of Islamic Community Guidance at the Ministry of Religion of Hulu Sungai Tengah Regency. These constraint factors will continue existing if they are not fixed or improved. Even though these problems are relatively minimal, it is important to always improve the sake satisfaction of service users.

Based on the research results, the constraint factors existing in the field of Islamic Community Guidance, especially in BP4 services are in the quantity and timeliness aspects. Specifically, the amount of ins and outs of monthly data on BP4 service users do not match. Time discrepancy is also one of the 
constraint factors, the estimated service time set by the Ministry of Religion of Hulu Sungai Tengah Regency in the field of Islamic Community Guidance, especially in BP4 services is one month, but on practice exceeds one month. This is because during the data mining process and at the time of the call for mediation, the person concerned has problems attending.

\section{Conclusion}

Based on the research that has been carried out in the field regarding service performance, it can be concluded that service performance of BP4 in the field of Islamic Community Guidance at the Ministry of Religion of Hulu Sungai Tengah Regency, which is a manifestation of the ability and success of an organization or agency in implementing policies, programs, and activities related to the implementation of tasks and functions, especially on performance indicators of quality, quantity, timeliness, cost effectiveness, need for supervision and interpersonal impact, is quite good.

The constraint factors existing in BP4 services in the field of Islamic Community Guidance are the incompatibility of the number of incoming and outgoing BP4 service users due to timeliness and the timeliness which does not meet the estimated time set by the Ministry of Religion of Hulu Sungai Tengah Regency because during the service delivery process there are obstacles such as service users not wanting to be present during the mediation process and difficulties in collecting service user data.

\section{References}

Antoni. 2019. Kinerja Pelayanan Pemerintah Dalam Menaikkan Pangkat Pegawai Negeri Sipil Pada Badan Kepegawaian dan Pengembangan Sumber Daya Manusia Kabupaten Barito Utara. [Tesis]Banjarmasin: Universitas Lambung Mangkurat

Astuti, Yuni Dwi. 2013. Hubungan Antara Budaya Organisasi dengan Kinerja Karyawan PT. PLN (Persero) Area Malang. [Tesis] Malang: Universitas Islam Negeri Maulana Malik Ibrahim

Beekun, Rafik Issa. 2004. Etika Bisnis Islam. Yogyakarta: Pustaka Pelajar

Darman. 2015. "Teori-Teori Manajemen Organisasi”, http://theorymanajemendanorganisasi.blogspot.com/, (Diakses pada tanggal 5 April 2021, Pukul 20.33)

Sugiyono. 2013. Metode Penelitian Pendidikan. Bandung: Alfabeta

Sulaksono, Hari. 2015. Budaya Organisasi dan Kinerja. Yogyakarta: Deepublish

Sundari. 2009. Analisis Kinerja Satuan Polisi Pamong Praja Kabupaten Kulon Progo Tahun 2008. [Skripsi] Yogyakarta: Universitas Muhammadiyah Yogyakarta

Undang-Undang Nomor 2005 Tahun 2009 tentang Pelayanan Publik

\section{Copyrights}

Copyright for this article is retained by the author(s), with first publication rights granted to the journal.

This is an open-access article distributed under the terms and conditions of the Creative Commons Attribution license (http://creativecommons.org/licenses/by/4.0/). 